\title{
MODERN SURGICAL MANAGEMENT OF BREAST CANCER THERAPY RELATED UPPER LIMB AND BREAST§
}

Nelson Leung ${ }^{a}$

Henk Giele ${ }^{b}$

Dominic Furniss ${ }^{b}$

aFoundation Programme, Oxford Deanery, Oxford Radcliffe Hospitals NHS Trust, Oxford OX3 9DU, UK

${ }^{\mathrm{b}}$ Department of Plastic and Reconstructive Surgery, Oxford Radcliffe Hospitals NHS Trust, Oxford OX3 9DU, UK

\section{ABSTRACT}

Breast cancer is the commonest cancer in the UK. Advances in breast cancer treatment means that the sequelae of treatment are affecting more women, and for a longer duration. Lymphoedema is one such sequela, with wide-ranging implications, from serious functional and psychological effects at the individual level to wider economic burdens to society.

Breast cancer-related lymphoedema is principally managed by conservative therapy comprising compression garments and manual decongestive massage. This approach is effective for early stages of lymphoedema, but it is not curative and it's effectiveness depends on patient compliance. Early surgical approaches were ablative, gave significant morbidity and hence, reserved for the most severe cases of refractory lymphoedema. However, recent non-ablative reconstructive surgical approaches have seen a revival of interest in the prevention or surgical management of breast cancerrelated lymphoedema.

This review examines the modern surgical techniques for the treatment of breast cancer-related lymphoedema. Liposuction reduces the volume and symptoms of lymphedema, but requires continual compressive therapy to avoid recurrence. Lymphatic reconstruction or bypass techniques including lymph node transfer (inguinal nodes are transferred to the affected limb), lymphaticolymphatic bypass (lymphatics bypass the axilla using a lymph vessel graft reconstructing lymphatic flow from arm to neck) and lymphaticovenous anastomoses (lymphatics in the arm are joined to the venous system aiding lymph drainage) show promise in reducing lymphedema significantly. Further research is required, including into the role of primary lymphaticovenous anastomoses in the prevention of lymphedema at the time of axillary dissection.

Keywords: lymphoedema, breast cancer related-lymphoedema, liposuction, lymph node transfer, lymphatico-lymphatic bypass, lymphaticovenous anastomoses 
Abbreviations. BCRL, breast cancer-related lymphoedema; LNT, lymph node transfer; LLB, lymphatico-lymphatic bypass; LVA, lymphaticovenous anastomoses

${ }^{*}$ Corresponding author. Telephone: ++ 441865223223 E-mail address:henk.giele2@ouh.nhs.uk ; Postal address: Department of Plastic and Reconstructive Surgery, Oxford Radcliffe Hospitals NHS Trust, Oxford OX3 9DU, UK 


\section{INTRODUCTION}

Breast cancer is the commonest cancer in women (1). In the UK, breast cancer is the commonest cancer overall, and accounts for $30 \%$ of all cancers in British women (2). In 2011, the age-standardized incidence rate was 125 per 100,000 women per year, and 50,285 new cases of breast cancer were diagnosed in the UK (2). The five-year survival rate for breast cancer in the UK is $85.1 \%$ (3) many of whom experience the complications of breast cancer treatment.

This paper reviews breast cancer-related lymphoedema (BCRL), a common complication of breast cancer treatment. The primary focus will be on the surgical management of this condition, which has undergone a renaissance in the last two decades. We performed a literature search and present the modern surgical approaches to prevention and management of BCRL, and provide recommendations for optimal management at different stages of disease. We also note the research needs of this surgical approach to BCRL.

\subsection{Breast Cancer-Related Lymphoedema}

Lymphoedema is the accumulation of protein rich fluid in the subcutaneous tissue and skin secondary to dysfunction of the lymphatic system. It may be primary (4), or secondary to infection, surgical lymphadenectomy, or radiotherapy (5). As the condition progresses, lymphatic stasis leads to inflammation, lipogenesis, fat deposition, and fibrosis (6). These pathological processes produce clinical manifestations represented by the lymphoedema staging system from the International Society of Lymphology (7) (Table 1).

Table 1 - International Society of Lymphology classification of lymphoedema (7)

\begin{tabular}{cl}
\hline Stage & \multicolumn{1}{c}{ Clinical Features } \\
\hline 0 & Subclinical lymphoedema without oedema but evidence of impaired lymphatic function \\
\hline 1 & Reversible pitting oedema. No palpable fibrosis. Negative or borderline Stemmer's sign \\
\hline $2 \mathrm{a}$ & Pitting oedema that is not reduced by elevation. Positive Stemmer's sign. \\
\hline $2 \mathrm{~b}$ & $\begin{array}{l}\text { Non-pitting oedema secondary to pronounced fibrosis. Presence of hyperkeratosis and } \\
\text { lymphostatic warts. Positive Stemmer's sign. }\end{array}$ \\
\hline 3 & $\begin{array}{l}\text { Lymphostatic elephantiasis. Progressive fibrosis, acanthosis, hyperkeratosis and } \\
\text { papillomatosis. Ulceration. }\end{array}$ \\
\hline
\end{tabular}

Stemmer's sign is the inability to pinch a fold of skin at the base of the second toe or in the upper limb the finger.

BCRL is caused by damage or destruction of the upper limb lymphatic drainage system by surgery, radiotherapy, chemotherapy, or combination treatment, or owing to the infiltration of lymphatics by the cancer itself (8). BCRL occasionally emerges immediately after surgery, but it most often appears after a latent period (9).

The incidence of BCRL after radical mastectomy, total mastectomy with axillary radiation and total mastectomy have been observed to be $58.1 \%, 38.3 \%$ and $49.1 \%$, respectively (10). For breast conserving surgery, the incidence varies 
considerably with the aggressiveness of treatment, from as low as $13 \%$ in patients who undergo breast conservation with sentinel lymph node biopsy without chemotherapy to as high as $61 \%$ or $65 \%$ in patients undergoing breast conservation and chemotherapy with axillary lymph node dissection or regional radiotherapy (11). Obesity is known to increase the risk of BCRL independent of treatment modality (12).

BCRL results in significant physical and psychological morbidity (13) (14). It interferes with mobility of the affected limb, causes a feeling of heaviness and discomfort, causes recurrent attacks of infection and inflammation (15-17), and also affects patients' self-perception, acting as a constant reminder of the cancer and its treatment. Economically, compared to breast cancer patients without $\mathrm{BCRL}$, those who developed BCRL incur considerably higher medical costs, ranging from 14,877 to 23,167 USD/year (18).

\subsection{Management of Breast Cancer-Related Lymphoedema}

$\mathrm{BCRL}$ is traditionally managed conservatively with complete decongestive physiotherapy, a fourfold approach of manual lymphatic drainage, compression, skin care and exercises (19). While the effectiveness of this approach has been documented in a number of studies $(20,21)$, the intense training required for it to be effective, along with the expectation that these measures must be continued for the rest of a patient's life, highlight considerable practical limitations.

Surgical management of BCRL has evolved significantly since Sistrunk (22) first applied the debulking principles of the Charles' (23) and Kondoleon's (24) operations to the upper limb. Modern techniques for treating or preventing lymphoedema after breast cancer treatment can be categorized as reductive and physiological.

The chief reductive approach is liposuction. This technique is often used as an adjunct to conservative management that should continue post-operatively. Physiological approaches comprise lymph node transfer (LNT), lymphaticovenous or lymphaticovenular anastomosis (LVA), and lymphaticolymphatic bypass (LLB).

In LNT, several lymph nodes within a block of tissue are taken from the groin and transplanted to the axilla, antecubital fossa or wrist as a vascularized free flap. These nodes are then thought to stimulate lymphangiogenesis, improving lymphatic clearance from the arm. In LVA, lymphatics are anastamosed to veins providing a physiological bypass of the disrupted lymphatic system in the axilla, and returning the lymphatic fluid to the circulation peripherally rather than centrally. Lymphovenous indicates a deeper larger anastomosis whereas lymphovenular indicates subcutaneous lymphatics being anastomosed to subdermal venules. In LLB, a long segment of a healthy lymphatic channel is harvested from the medial thigh, and like an interposition vein graft is anastomosed from lymphatic channels in the arm to channels in the neck in order to bypass the obstructed lymphatics in the axilla. 


\section{METHODS}

We searched Medline from inception to February 2014 using the following strategy:

1 *Lymphatic Vessels/su [Surgery] (102)

2 *Lymphedema/su [Surgery] (662)

31 or $2(713)$

4 lymphedema.ab,ti. (4182)

5 lymphoedema.ab,ti. (1457)

6 *lymphedema/ (5269)

74 or 5 or $6(7214)$

83 and 7 (669)

9 limit 8 to (english language and humans and journal article) (346)

We included all studies that reported on the efficacy of modern surgical techniques used for the prevention or treatment of BCRL, published after 2000 in order to include only modern surgical techniques. Reference lists of relevant articles were searched for additional studies.

\section{RESULTS}

\subsection{Reductive approach}

\subsubsection{Liposuction}

Subcutaneous lymphoedematous tissue, (mainly fat and fluid) is removed via suction using cannulae (25). Liposuction decreases the volume of lymphoedema and also reduces the incidence of cellulitis by decreasing the volume of proteincontaining tissue (25).

The efficacy of liposuction for BCRL produced modest results that were improved when treatment was combined with a garment (26), while treatment which mandated compression garments (27), reported a mean decrease in lymphoedema volume of $23 \%$.

Brorson (28) combined this operative approach with controlled compression therapy (CCT), producing $106 \%$ mean percentage reduction. Numerous surgeons have adopted this method, and results of the most recent studies are presented in Table 2.

Table 2 - Liposuction for BCRL, 2000 - present

\begin{tabular}{lllll}
\hline Study & $\begin{array}{l}\text { n, mean } \\
\text { follow-up }\end{array}$ & Results & Complications & $\begin{array}{l}\text { Additional } \\
\text { interventions }\end{array}$ \\
\hline Schaverien et & $11,3.2 \mathrm{yrs}$ & Volumetry & No operative & CCT \\
\hline
\end{tabular}




\begin{tabular}{|c|c|c|c|c|}
\hline al (29) & & MPR $^{a}$ at 1 year: $101 \%$ & complications & \\
\hline $\begin{array}{l}\text { Damstra et al } \\
(30)\end{array}$ & $37,1 \mathrm{yr}$ & $\begin{array}{l}\text { Volumetry } \\
\text { MPR at } 1 \text { year: } 118 \%\end{array}$ & $\begin{array}{l}\text { No operative } \\
\text { complications }\end{array}$ & CCT \\
\hline Brorson (25) & $24,1 \mathrm{yr}$ & $\begin{array}{l}\text { Volumetry } \\
\text { MPR at } 1 \text { year: } 106 \%\end{array}$ & Not mentioned & CCT \\
\hline
\end{tabular}

${ }^{\mathrm{a}} \mathrm{MPR}=$ mean percentage reduction $=[(a-b)-(c-d)] /(a-b)$, where $a$ is the pre-operative volume or circumference of the lymphoedematous arm, $\mathrm{b}$ is the pre-operative volume or circumference of the normal arm, $\mathrm{c}$ is the post-operative volume or circumference of the lymphoedematous arm, and $d$ is the post-operative volume or circumference of the normal arm.

Liposuction combined with compressive garments achieves a sustained reduction of arm lymphoedema. However, a custom-made compression garment needs to be worn for 24 hours a day for life, and adjusted intermittently to compensate for the reduced elasticity of the garment and/or changing arm volume in order to maintain the success of this technique (25). This is a clear disadvantage as for many patients a goal of surgical treatment is to obviate the need for continued compression.

\subsection{Physiological Approach}

\subsubsection{Lymph Node Transfer}

This technique comprises of the transfer of healthy vascularized lymph nodes within a block of tissue from the groin to the lymphoedematous limb. The mechanism of action is unknown, possibly the transfer of healthy lymph nodes and lymphatics either directly drains excess lymph fluid from oedematous areas, via intra-flap lymphatico-venous connections, or encourages new lymphatic vessels to sprout in the region (31).

The two main types of autologous lymph node transfer techniques are separate free groin inguinal node flaps or as part of the breast reconstruction the abdominal flap used is designed to contain lymph nodes. Becker et al (32) first described the vascularized transfer of inguinal lymph nodes to the affected axilla using a flap based on the deep branch of the superficial circumflex iliac artery (SCIA). Lin et al (33) used the affected wrist as the recipient site, because of the technical difficult of finding recipient vessels in an axilla scarred by radiation and surgery. Gharb et al (34) included the superficial branch of the SCIA and its perforating vessels to improve the viability of transplanted lymph nodes. The results of vascularized inguinal LNT are in Table 3.

Table 3 - Free groin flaps for BCRL, 2000 - present

\begin{tabular}{|c|c|c|c|c|}
\hline Study & $\begin{array}{l}\text { n, mean } \\
\text { follow-up }\end{array}$ & Results & Complications & $\begin{array}{l}\text { Additional } \\
\text { interventions }\end{array}$ \\
\hline $\begin{array}{l}\text { Cheng et al } \\
\text { (35) }\end{array}$ & $10,37 \mathrm{mo}$ & $\begin{array}{l}\text { Circumference } \\
\text { MPR: } 40.4 \%\end{array}$ & $\begin{array}{l}\text { 1x transient donor site } \\
\text { oedema }\end{array}$ & None \\
\hline $\begin{array}{l}\text { Gharb et al } \\
\text { (34) }\end{array}$ & $21,46 \mathrm{mo}$ & $\begin{array}{l}\text { Circumference } \\
\text { PvPCD }^{\mathrm{a}} \text { standard group }{ }^{\mathrm{b}}(\mathrm{n}=11) \text { : } \\
\text { no change } \\
\text { PvPCD perforator-based group } \\
\text { ( } \mathrm{n}=10) \text { : reduction at elbow, wrist } \\
\text { and midpalm; no change above } \\
\text { elbow }\end{array}$ & $\begin{array}{l}\text { No. complications of } \\
\text { standard group }>\text { no. } \\
\text { complications of } \\
\text { perforator-based group }\end{array}$ & Physiotherapy \\
\hline Lin et al (33) & $13,56 \mathrm{mo}$ & $\begin{array}{l}\text { Circumference } \\
\text { MPR: } 50.6 \%\end{array}$ & $\begin{array}{l}1 \mathrm{x} \text { wound infection } \\
1 \mathrm{x} \text { venous congestion }\end{array}$ & Not mentioned \\
\hline
\end{tabular}




\begin{tabular}{lll}
\hline $\begin{array}{l}\text { Becker et al 24, 8.3yrs } \\
\text { (32) }\end{array}$ & $\begin{array}{l}\text { Circumference } \\
\text { Decreased: } 22 \text { (10 returned to } \\
\text { pre-lymphoedema state) } \\
\text { Unchanged: } 2\end{array}$ & Physiotherapy \\
\hline aPvPCD = pre- versus post-op circumference difference & \\
bStandard group = groin flap based on the deep branch of the SCIA
\end{tabular}

The evidence for the efficacy of lymph node transfer is inconclusive While the Becker study (32) reported that 10 of 24 patients experienced a complete reduction of their lymphoedema, Gharb et al (34) was unable to produce a statistically significant post-operative reduction in circumference in their standard group, which utilized the Becker technique to harvest the flap. In fact, 8 of 11 patients in the study's standard group required further liposuction to manage their BCRL. Moreover, LNT is not without its risks, with one of the most serious being the potential development of lymphoedema at the donor site (35).

Breast reconstruction using lower abdominal reconstruction flaps with inguinal lymph nodes included, have also been used to manage BCRL(37). Interestingly, breast reconstruction using a pedicled latissimus dorsi flap with no obvious lymph nodes included also leads to an objective improvement of lymphoedema (36). Results of these studies are presented in Table 4.

Table 4 - Breast reconstruction flaps for BCRL, 2000 - present

\begin{tabular}{lllll}
\hline Study & $\begin{array}{l}\text { n, mean } \\
\text { follow-up }\end{array}$ & Results & Complications & $\begin{array}{l}\text { Additional } \\
\text { interventions }\end{array}$ \\
\hline $\begin{array}{l}\text { Saaristo et al } \\
\text { (37) }\end{array}$ & $9,6 \mathrm{mo}$ & $\begin{array}{l}\text { Circumference } \\
\text { Post-op vs pre-op: reduction in } 7 \\
\text { cases, no change in 2 cases }\end{array}$ & $\begin{array}{l}\text { 3x seroma } \\
\text { 2x delayed abdominal } \\
\text { wound closure }\end{array}$ & $\begin{array}{l}\text { Physiotherapy } \\
\text { Compression } \\
\text { garments }\end{array}$ \\
\hline $\begin{array}{l}\text { Abbas Khan } \\
\text { et al (36) }\end{array}$ & $3,5.7 y r s$ & $\begin{array}{l}\text { Volume } \\
\text { Rate of improvement of } \\
\text { lymphoedema: } 2.55 \mathrm{ml} / \mathrm{wk} \\
\text { (versus } 0.095 \mathrm{ml} / \mathrm{wk} \text { for } \\
\text { conservative measures) }\end{array}$ & Not mentioned & Not specified \\
& & & \\
\hline
\end{tabular}

\subsubsection{Lymphatico-lymphatic bypass}

Ho et al (38) and Baumeister et al (39) were the first to approach BCRL by utilizing healthy lymphatic vessels. In their methods, grafts of lymphatic vessels harvested from the ventromedial aspect of the thigh are interposed, via end-toend anastomoses, between the ascending lymphatics of the affected arm and the more centrally located lymphatics in the neck to bypass areas of axillary lymphatic obstruction. Campisi (40) used a vein rather than lymphatic vessel to bridge the area of obstruction. Felmerer et al (41) recently published a report of his experience using the Baumeister method. The results are summarized in Table 5.

Table 5 - Lymphatico-lymphatic bypass for BCRL, 2000 - present

\begin{tabular}{|c|c|c|c|c|}
\hline Study & $\begin{array}{l}n, \text { mean } \\
\text { follow-up }\end{array}$ & Results & Complications & $\begin{array}{l}\text { Additional } \\
\text { interventions }\end{array}$ \\
\hline
\end{tabular}




\begin{tabular}{lllll}
\hline $\begin{array}{l}\text { Felmerer et al } \\
(41)\end{array}$ & $7,2.6 y r s$ & Circumference & Cellulitis, donor site & Physiotherapy \\
& & Complete recovery: 1 & lymphorrhoea, transient & Compression \\
& & Reasonable outcome: 6 & oedema of donor leg & garments
\end{tabular}

It is notable that four patients in the above study were able to maintain their improvements during the follow-up period without the need to continue physiotherapy or compression garments (41). Baumeister and Siuda (42) further demonstrated the high patency rate of the lymphatic graft, thought to be favourable in comparison to bypasses involving veins prone to thrombotic occlusion (43). However, LLB does leave a long scar in the thigh, and one particularly serious consideration is the risk of developing lymphoedema at the donor site. Bilateral leg lymphoedema is a contraindication to LLB (41).

\subsubsection{Lymphaticovenular anastomosis}

O'Brien et al (44) popularized the technique of diverting lymphatic fluid into the venous system before it reaches an area of lymphatic compromise, by anastomosing lymphatics to veins, thus providing a physiological bypass. The specific method of diversion is variable either using end-to-end or end-to-side anastomoses, implanting a lymphatic vessel inside the lumen of large vein (45), or performing end-to-end LVA between smaller lymphatic vessels and venules (43). The implantation of a group of divided lymphatic vessels into a large vein has also been described (46). Koshima et al (47) advocated anastomosing tiny subdermal lymphatics and venules with supermicrosurgery, hypothesizing that minimal backflow would occur across these superficial connections especially when the lymphatic pressure is raised in lymphoedema (48).

LVA surgery is facilitated by using indocyanine green fluorescence (ICG) lymphography (49). This is used preoperatively and intraoperatively to map the location of sub-dermal lymphatic channels, potentially improving outcomes, and reducing operating time (50-52). Chang et al (50) reported that an average of 2 extra bypasses were achieved at each operation after ICG lymphography was introduced. Furukawa et al (53) utilized ICG lymphography but rather than map areas of intact lymphatic flow, but they targeted areas with high dermal backflow of the dye, indicating lymphatic malfunction. They hypothesized that by performing lymphatico-venous anastomosis (46) in areas where there was lymphatic obstruction, the high intra-lymphatic pressure would drive the drainage of lymph into the venous system.

Table 6 summarizes the results of studies.

Table 6 - Lymphatico-venous bypass for BCRL, 2000 - present

\begin{tabular}{lllllll}
\hline Study & $\begin{array}{l}\text { n, mean } \\
\text { follow-up }\end{array}$ & ICG & LVA & Results & Complications & Additional interventior \\
\hline $\begin{array}{l}\text { Chang et al } \\
(50)\end{array}$ & $89,30.4 \mathrm{mo}$ & Yes & $\begin{array}{l}\text { Sub- } \\
\text { dermal }\end{array}$ & $\begin{array}{l}\text { Volume } \\
\text { MPR at } 1 \mathrm{yr}: 42 \% \\
\text { MPR stage } 1 / 2 \text { at } 1 \mathrm{yr}: 61 \% \\
\text { MPR stage } 3 / 4 \text { at } 1 \mathrm{yr}: 17 \%\end{array}$ & $\begin{array}{l}\text { No post-op } \\
\text { complications }\end{array}$ & $\begin{array}{l}\text { Physiotherapy } \\
\text { Compression garments }\end{array}$ \\
\hline $\begin{array}{l}\text { Auba et al } \\
(55)\end{array}$ & $6,18 \mathrm{mo}$ & No & $\begin{array}{l}\text { Sub- } \\
\text { dermal }\end{array}$ & $\begin{array}{l}\text { Circumference } \\
\text { Mean reduction: } 0.85 \mathrm{~cm}\end{array}$ & Not mentioned & Compression garments \\
\hline
\end{tabular}




\begin{tabular}{|c|c|c|c|c|c|c|}
\hline $\begin{array}{l}\text { Furukawa et } \\
\text { al (53) }\end{array}$ & $9,17 \mathrm{mo}$ & Yes & $\begin{array}{l}\text { Sleeve } \\
\text { end to } \\
\text { side }\end{array}$ & $\begin{array}{l}\text { Circumference } \\
>50 \% \text { reduction oedema at distal } \\
\text { and proximal sites: } 3 \\
>50 \% \text { reduction oedema at either } \\
\text { distal or proximal site: } 4 \\
\leq 50 \% \text { reduction oedema at both } \\
\text { sites with subjective improvement: } 2 \\
\leq 50 \% \text { reduction oedema at both } \\
\text { sites without subjective } \\
\text { improvement: } 0\end{array}$ & Not mentioned & Compression garments \\
\hline Chang (56) & $20,18 \mathrm{mo}$ & No & $\begin{array}{l}\text { Sub- } \\
\text { dermal }\end{array}$ & $\begin{array}{l}\text { Volume } \\
\text { MPR at } 1 \mathrm{yr}: 35 \%\end{array}$ & $\begin{array}{l}\text { No post-op } \\
\text { complications }\end{array}$ & $\begin{array}{l}\text { Physiotherapy } \\
\text { Compression garments }\end{array}$ \\
\hline $\begin{array}{l}\text { Damstra et } \\
\text { al (54) }\end{array}$ & $10,8 y r s$ & No & $\begin{array}{l}\text { End to } \\
\text { side }\end{array}$ & $\begin{array}{l}\text { Volume } \\
\text { MPR at 1yr: } 2 \%\end{array}$ & Not mentioned & Compression garments \\
\hline $\begin{array}{l}\text { Koshima et } \\
\text { al (47) }\end{array}$ & $12,2.2 \mathrm{yrs}$ & No & $\begin{array}{l}\text { Sub- } \\
\text { dermal }\end{array}$ & $\begin{array}{l}\text { Circumference } \\
\text { Mean reduction: } 4.1 \mathrm{~cm} \\
\text { MPR: } 47.3 \%\end{array}$ & Not mentioned & Compression garments \\
\hline
\end{tabular}

Using their own staging criteria (50), they also reported improved results when they performed LVA in patients with stage 1 and 2 lymphoedema, compared to patients with stage 3 and 4 lymphoedema.

The use of LVA as a preventative measure has also been studied. Boccardo et al (57) examined the efficacy of a LVA performed during axillary node dissection, in preventing the development of BCRL. In this study, 46 women who underwent complete axillary dissection were randomized to receive a LVA or no preventative surgical procedure. In the LVA group, at 18 months follow up, 1 patient (4.34\%) developed lymphoedema, compared to 7 patients $(30.43 \%)$ in the control group. There was no increased rate of complications in the LVA group. LVA may be a promising preventative strategy for preventing BCRL.

\section{DISCUSSION}

Over the last decade, there has been a renewal of interest in surgical techniques to prevent or treat BCRL. In this review we have summarized the literature relating to modern surgical treatments, and several themes can be discerned.

First, the excisional approach to BCRL is effective at reducing limb volume. However, liposuction is only a reliable method for reducing limb volume provided the patient is compliant with lifelong CCT. Many patients with lymphoedema wish to be free from compression garments.

The evidence on the use of vascularized LNT using groin flaps is contradictory. The operation requires a prolonged general anaesthetic and hospital stay. The mechanism of action of the procedure is also not known. There is a risk for developing donor site lymphoedema. Utilization of vascularized LNT as part of a planned breast reconstruction has advantages, in that it is unlikely to significantly increase the morbidity of the procedure, and might improve the lymphoedema. Without clear evidence of efficacy, we believe that LNT should be confined to clinical trials. 
LLB is effective in the hands of the group that has published their outcomes, however, the generalizability of these results is yet to be established. Furthermore, this operation leaves a large scar in the thigh region and there is a risk of donor site lymphoedema.

LVA is a reasonably studied approach with promise not only in treating early stage BCRL, but also in preventing lymphedema from occurring. It is conceptually attractive in providing a route for the lymph fluid to return to the venous circulation distally, bypassing the area of lymphatic obstruction. LVA is minimally invasive, and can be performed under local anaesthesia as a day-case procedure. The procedure is technically demanding, and requires resources such as ICG lymphography to optimize outcomes. The results of LVA seems to be better for earlier stage disease, and more studies are required to define the indications and expected outcomes of surgery. We summarize our recommended approach to the prevention and treatment of BCRL in figure 1.

\section{ISL Stage}

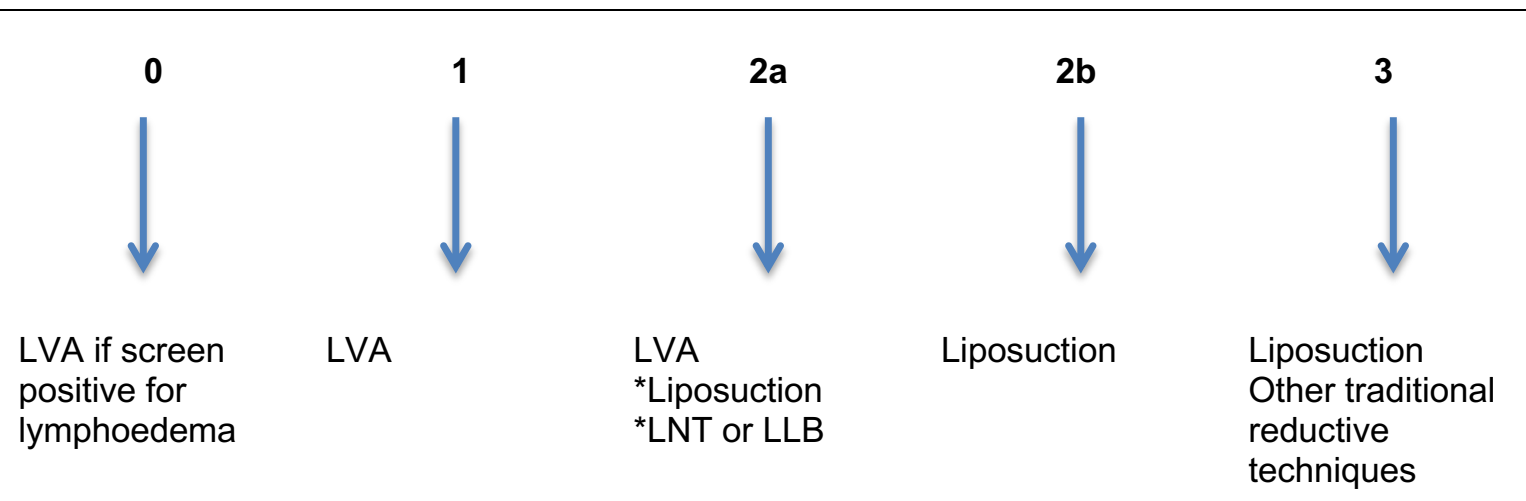

Figure 1 - Recommended algorithm for the surgical prevention and treatment of BCRL. For ISL stage 0 patients, those deemed high risk (axillary surgery with chemo- and/or radiotherapy) should be screened for early lymphoedema with perometry, bioimpedance or ICG lymphography. If diagnosed, LVA is recommended. For ISL stage 2a patients, liposuction may be considered if volume reduction is the main aim and the patient is compliant with lifelong CCT; LNT or LLB may be considered as part of clinical studies.

\subsection{Future Research}

This review has highlighted research needs within several areas relating to BCRL. In the first instance, standardized methods for the diagnosis or measurement of BCRL are lacking. Methods that predict those patients who are going to develop BCRL would allow early intervention to be targeted at those high-risk groups. ICG lymphography has been shown to predict lymphoedema following pelvic lymph node dissection for gynaecological malignancy (58), and this approach may also be useful in BCRL in the future. 
Secondly, there is a clear need for randomized controlled trials to define the most appropriate intervention for each stage of lymphoedema. Such trials should compare surgical interventions with conservative treatments, and also with other surgical interventions.

Thirdly, vital to the success of such trials is adequately defining the outcomes that patients value within this field. Lymphoedema affects the quality of life of patients in ways that are not encapsulated by simple measurements of circumference or volume of the limb, and interventions need to address more than this objective outcome.

Lastly, the involvement of patients in the design, conduct and analysis of randomized controlled trials is important to ensure that acceptable study designs are implemented that can answer questions important to them. Ideally, a James Lind Alliance priority setting partnership where patients, carers, therapists, physicians, and surgeons with an interest in BCRL come together to decide on the top research priorities within the area should be undertaken.

Conclusion.

Breast cancer therapy related lymphedema is a difficult problem for patients and their carers. The developing modern surgical management of BCRL has a role in the management of these patients.

\section{Contributors}

NL performed the searches and wrote the first draft of the manuscript. DF and HG critically evaluated and revised the manuscript. All authors approved the final version of the manuscript.

\section{Competing interest}

None

\section{Funding}

None

\section{Provenance and peer review}

Commissioned. Peer reviewed.

\section{Acknowledgements}

Authors would like to thank Tatjana Petrovic, librarian, for her help with formulating the search strategy. 


\section{References}

1. Organization WH. Breast cancer: prevention and control. 2014

2. UK CR. Cancer incidence for common cancers: Cancer Research UK. 2014

3. UK CR. Breast cancer statistics: Cancer Research UK. 2014

4. Connell F, Brice G, Jeffery S, Keeley V, Mortimer P, Mansour S. A new classification system for primary lymphatic dysplasias based on phenotype. Clin Genet. 2010;77:438-452.

5. Warren AG, Brorson H, Borud LJ, Slavin SA. Lymphedema: a comprehensive review. Ann Plast Surg. 2007;59:464-472.

6. Ryan TJ. Lymphatics and adipose tissue. Clin Dermatol. 1995;13:493-498.

7. Lymphology ISo. The diagnosis and treatment of peripheral lymphedema. 2009 Concensus Document of the International Society of Lymphology. Lymphology. 2009;42:51-60.

8. Brennan MJ, DePompolo RW, Garden FH. Focused review: postmastectomy lymphedema. Arch Phys Med Rehabil. 1996;77:S74-S80.

9. Clodius L. Lymphoedema common sense. European Journal of Plastic Surgery. 2002;25:66-80.

10. Deutsch M, Land S, Begovic M, Sharif S. The incidence of arm edema in women with breast cancer randomized on the National Surgical Adjuvant Breast and Bowel Project study B-04 to radical mastectomy versus total mastectomy and radiotherapy versus total mastectomy alone. Int J Radiat Oncol Biol Phys. 2008;70:1020-1024.

11. Gartner R, Jensen MB, Kronborg L, Ewertz M, Kehlet H, Kroman N. Selfreported arm-lymphedema and functional impairment after breast cancer treatment--a nationwide study of prevalence and associated factors. Breast. 2010;19:506-515.

12. DiSipio T, Rye S, Newman B, Hayes S. Incidence of unilateral arm lymphoedema after breast cancer: a systematic review and meta-analysis. Lancet Oncol. 2013;14:500-515.

13. Pusic AL, Cemal Y, Albornoz $C$ et al. Quality of life among breast cancer patients with lymphedema: a systematic review of patient-reported outcome instruments and outcomes. J Cancer Surviv. 2013;7:83-92.

14. Tobin MB, Lacey HJ, Meyer L, Mortimer PS. The psychological morbidity of breast cancer-related arm swelling. Psychological morbidity of lymphoedema. Cancer. 1993;72:3248-3252.

15. Badger C, Mortimer P, Regnard C, Twycross R. Pain in the Chronically Swollen Limb, Progress in Lymphology - XI. Vienna: Elsevier Science Publishers; 1988:243.

16. Carroll D, Rose K. Treatment leads to significant improvement. Effect of conservative treatment on pain in lymphoedema. Prof Nurse. 1992;8:32-3, 35.

17. Mortimer PS. Managing lymphoedema. Clin Exp Dermatol. 1995;20:98-106.

18. Shih YC, Xu Y, Cormier JN et al. Incidence, treatment costs, and complications of lymphedema after breast cancer among women of working 
age: a 2-year follow-up study. J Clin Oncol. 2009;27:2007-2014.

19. E F. The treatment of lymphedema. Cancer. 1998;83:2833-2834.

20. Bunce IH, Mirolo BR, Hennessy JM, Ward LC, Jones LC. Post-mastectomy lymphoedema treatment and measurement. Med J Aust. 1994;161:125-128.

21. Casley-Smith JR. Alterations of untreated lymphedema and it's grades over time. Lymphology. 1995;28:174-185.

22. Sistrunk WE. Contribution to plastic surgery: Removal of scars by stages; an open operation for extensive laceration of the anal sphincter; the Kondoleon operation for elephantiasis. Ann Surg. 1927;85:185-193.

23. Charles R. Elephantiasis Scroti. London: Churchill; 1912

24. Kondoleon E. Die operative Behandlung der elephantiastischen Odema. Zentralbl Chir. 1912;39:1022.

25. Brorson $\mathrm{H}$. Liposuction gives complete reduction of chronic large arm lymphedema after breast cancer. Acta Oncol. 2000;39:407-420.

26. Sando WC, Nahai F. Suction lipectomy in the management of limb lymphedema. Clin Plast Surg. 1989;16:369-373.

27. O'Brien BM, Khazanchi RK, Kumar PA, Dvir E, Pederson WC. Liposuction in the treatment of lymphoedema; a preliminary report. Br J Plast Surg. 1989;42:530-533.

28. Brorson $\mathrm{H}$, Svensson $\mathrm{H}$. Complete reduction of lymphoedema of the arm by liposuction after breast cancer. Scand J Plast Reconstr Surg Hand Surg. 1997;31:137-143.

29. Schaverien MV, Munro KJ, Baker PA, Munnoch DA. Liposuction for chronic lymphoedema of the upper limb: 5 years of experience. J Plast Reconstr Aesthet Surg. 2012;65:935-942.

30. Damstra RJ, Voesten HG, Klinkert P, Brorson H. Circumferential suctionassisted lipectomy for lymphoedema after surgery for breast cancer. $\mathrm{Br} \mathrm{J}$ Surg. 2006;96:859-864.

31. Suami H, Chang DW. Overview of surgical treatments for breast cancerrelated lymphedema. Plast Reconstr Surg. 2010;126:1853-1863.

32. Becker C, Assouad J, Riquet M, Hidden G. Postmastectomy lymphedema: long-term results following microsurgical lymph node transplantation. Ann Surg. 2006;243:313-315.

33. Lin $\mathrm{CH}$, Ali R, Chen SC et al. Vascularized groin lymph node transfer using the wrist as a recipient site for management of postmastectomy upper extremity lymphedema. Plast Reconstr Surg. 2009;123:1265-1275.

34. Gharb BB, Rampazzo A, Spanio di Spilimbergo S, Xu ES, Chung KP, Chen $\mathrm{HC}$. Vascularized lymph node transfer based on the hilar perforators improves the outcome in upper limb lymphedema. Ann Plast Surg. 2011;67:589-593.

35. Cheng MH, Chen SC, Henry SL, Tan BK, Lin MC, Huang JJ. Vascularized groin lymph node flap transfer for postmastectomy upper limb lymphedema: flap anatomy, recipient sites, and outcomes. Plast Reconstr Surg. 2013;131:1286-1298.

36. Abbas Khan MA, Mohan A, Hardwicke $\mathrm{J}$ et al. Objective improvement in upper limb lymphoedema following ipsilateral latissimus dorsi pedicled flap 
breast reconstruction--a case series and review of literature. J Plast Reconstr Aesthet Surg. 2011;64:680-684.

37. Saaristo AM, Niemi TS, Viitanen TP, Tervala TV, Hartiala P, Suominen EA. Microvascular breast reconstruction and lymph node transfer for postmastectomy lymphedema patients. Ann Surg. 2012;255:468-473.

38. Ho LC, Lai MF, Kennedy PJ. Micro-lymphatic bypass in the treatment of obstructive lymphoedema of the arm: case report of a new technique. $\mathrm{Br} \mathrm{J}$ Plast Surg. 1983;36:350-357.

39. Baumeister RG, Siuda S, Bohmert H, Moser E. A microsurgical method for reconstruction of interrupted lymphatic pathways: autologous lymph-vessel transplantation for treatment of lymphedemas. Scand J Plast Reconstr Surg. 1986;20:141-146.

40. Campisi C. Use of autologous interposition vein graft in management of lymphedema: preliminary experimental and clinical observations.

Lymphology. 1991;24:71-76.

41. Felmerer G, Sattler T, Lohrmann C, Tobbia D. Treatment of various secondary lymphedemas by microsurgical lymph vessel transplantation. Microsurgery. 2012;32:171-177.

42. Baumeister RG, Siuda S. Treatment of lymphedemas by microsurgical lymphatic grafting: what is proved? Plast Reconstr Surg. 1990;85:64-74; discussion 75.

43. Yamada Y. Studies on lymphatic venous anastomosis in lymphedema. Nagoya J Med Sci. 1969;32:1-21.

44. O'Brien BM, Sykes P, Threlfall GN, Browning FS. Microlymphaticovenous anastomoses for obstructive lymphedema. Plast Reconstr Surg. 1977;60:197-211.

45. Sedlacek J. Lymphovenous shunt as supplementary treatment of elephantiasis of lower limbs. Acta Chir Plast. 1969;11:157-162.

46. Yamamoto $\mathrm{Y}$, Sugihara T. Microsurgical lymphaticovenous implantation for the treatment of chronic lymphedema. Plast Reconstr Surg. 1998;101:157161.

47. Koshima I, Inagawa K, Urushibara K, Moriguchi T. Supermicrosurgical lymphaticovenular anastomosis for the treatment of lymphedema in the upper extremities. J Reconstr Microsurg. 2000;16:437-442.

48. Olszewski WL, Engeset A. Intrinsic contractility of prenodal lymph vessels and lymph flow in human leg. Am J Physiol. 1980;239:H775-H783.

49. Kitai T, Inomoto T, Miwa M, Shikayama T. Fluorescence navigation with indocyanine green for detecting sentinel lymph nodes in breast cancer. Breast Cancer. 2005;12:211-215.

50. Chang DW, Suami H, Skoracki R. A prospective analysis of 100 consecutive lymphovenous bypass cases for treatment of extremity lymphedema. Plast Reconstr Surg. 2013;132:1305-1314.

51. Ogata F, Narushima M, Mihara M, Azuma R, Morimoto Y, Koshima I. Intraoperative lymphography using indocyanine green dye for near-infrared fluorescence labeling in lymphedema. Ann Plast Surg. 2007;59:180-184.

52. Suami H, Chang DW, Yamada K, Kimata Y. Use of indocyanine green 
fluorescent lymphography for evaluating dynamic lymphatic status.[letter]. Plast Reconstr Surg 2011;127(3):74e-76e.

53. Furukawa H, Osawa M, Saito A et al. Microsurgical lymphaticovenous implantation targeting dermal lymphatic backflow using indocyanine green fluorescence lymphography in the treatment of postmastectomy lymphedema. Plast Reconstr Surg. 2011;127:1804-1811.

54. Damstra RJ, Voesten HG, van Schelven WD, van der Lei B. Lymphatic venous anastomosis (LVA) for treatment of secondary arm lymphedema. A prospective study of 11 LVA procedures in 10 patients with breast cancer related lymphedema and a critical review of the literature. Breast Cancer Res Treat. 2009;113:199-206.

55. Auba C, Marre D, Rodriguez-Losada G, Hontanilla B. Lymphaticovenular anastomoses for lymphedema treatment: 18 months postoperative outcomes. Microsurgery. 2012;32:261-268.

56. Chang DW. Lymphaticovenular bypass for lymphedema management in breast cancer patients: a prospective study. Plast Reconstr Surg. 2010;126:752-758.

57. Boccardo FM, Casabona F, Friedman D et al. Surgical prevention of arm lymphedema after breast cancer treatment. Ann Surg Oncol. 2011;18:25002505.

58. Akita S, Mitsukawa N, Kuriyama M et al. Suitable therapy options for subclinical and early-stage lymphoedema patients. J Plast Reconstr Aesthet Surg. 2014;67:520-525. 